\title{
The Effect of Ownership Structure on Company Performance: Evidence from Emerging Market
}

\section{Mohammed H. Alsamhi ${ }^{1}$, Mohammed S. Barakat ${ }^{2}$,Waleed M. Alahdal ${ }^{3 *}$}

\author{
${ }^{1}$ Associate professor, Faculty of Management Sciences, Ibb University, Yemen \\ ${ }^{2}$ Assistant professor, Department of Accounting, University of Science \& Technology, Yemen \\ ${ }^{3}$ Research Scholar, Faculty of Commerce, Banaras Hindu University, India
}

\begin{tabular}{llllll}
\hline Received: 22.12 .2020 & • Accepted: 24.12.2020 & • & Published: 25.12.2020 & • Final Version: 25.12.2020
\end{tabular}

\begin{abstract}
This paper uses panel data to examine the impact of ownership structure index on the financial performance of 73 listed companies of the Indian national stock exchange from 2009 to 2016. To measure the Panel Regression in this study, the FEM model was used. The different dimensions of the ownership structure index involve ten items used as the Independent variable of this study. Two measures have been adopted to estimate the firm performance that is; ROA and ROE. In contrast, the control variables are firm size and leverage. This study's empirical evidence shows that the ownership structure index has significant impact on a firm's performance measured by ROA and ROE of Indian Nifty 100 listed companies. Findings of this study support previous empirical studies performed and add some value in the research area of finance that explores different aspects of the board of directors' index and ownership structure index in Indian market by using Nifty 100 as an example.
\end{abstract}

Keywords: Ownership structure, Company Performance, India

\section{Introduction}

The ownership structure is usually determined by some corporate governance characteristics which work at the country level, i.e., regulations guiding the stock market, nature of the state intervention, stock market development (La Porta et al., 1998). Company course is affected by the ownership structure, which affects the company's performance and achieves the company's goal to maximize the company's value. Companies set goals within their business operations. The company's goal is short-term and long-term; a short-term goal is limited to a specific period for generating a profit, and the long-term goal of a company is to maximize the value of the company(Rusyda, 2018). Ownership concentration of a firm is essential as it can limit(or influence) managers ability of a firm to divert firms profit as a pecuniary benefit to themselves or to the controlling shareholders in the form of private control benefit, which could hurt non-controlling shareholders of the company who does not have any controlling stake in the firm by a reduction in the value of the firm(Ozili \& Uadiale, 2017).

The ownership structure is known as the distribution of equity with relation to voting rights, capital, and the identity of equity owners (Himmelberg et al., 1999). The ownership structure will have different motivations to monitor the company and its management and board of directors. It will affect the company course, and finally, a company course will have an effect on a company's performance. During the last four decades, researchers have believed that ownership structure and firm performance are connected somehow. Almudehki \& Zeitun (2011) explained in their study that

\footnotetext{
*Corresponding Author:wm.alahdal2011@gmail.com
} 
the firm's performance was negatively affected by the diffuseness of shareholdings through an inverse relationship.

Financial information is provided through a primary channel that is a corporate financial statement, which enables external investors and users to make informed decisions. The effectiveness of operations is demonstrated by the company's performance and acts as a source for assessing the success of company related growth, performance, and the company's value. Financial performance was thus increased by an increase in institutional ownership that will impact the company's value by expanding it. The empirical results from previous studies of the effects of the board of director's index and ownership structure index on company performance have been mixed and inconclusive (Almudehki \& Zeitun, 2011; Eulaiwi et al., 2016; Fauzi \& Musallam, 2015; Srivastava \& Bhatia, 2020). This study contributes by increasing research on the effect of ownership structure index on Indian listed companies' firm performance. This study also provides a better understanding of the relationship between ownership structure index and other firms' characteristics, such as firm size and leverage on athletic performance. Besides, this study also hopes to add further evidence on the relationship of ownership structure index to the firm performance from the past studies in India and other countries.

The paper is structured as follows: Section 2 presents the related literature review. Section 3 describes the data and research methodology. Section 4 provides descriptions of the data and research methodology. Section 5 shows the econometric results and discussions. Section 6 presents the conclusion of the study.

\section{Literature Review}

The positive effect of managerial ownership on company value is explained by Fauzi \& Musallam (2015) that Managerial ownership may cause managers to act according to shareholders' wishes because managers will be motivated to improve performance to create high Company Value. The existence of managerial ownership leads management to participate in corporate decision making actively. Managerial ownership will align management and stockholder interests to benefit directly from the decisions taken and bear the losses as a consequence of wrong decision making (Rusyda, 2018).

However, Al-Matari et al.,(2017) examined the direct impact of concentration and managerial ownership on firm performance (ROA) among non-financial firms in Oman for the years 2010 until 2014. A positive and significant effect was found of ownership concentration on ROA. And a positive and insignificant association was found between managerial ownership and ROA. Also, Almudehki \& Zeitun (2011) studied the impact on corporate performance due to the different dimensions of ownership structure. Twenty-nine non-financial firms were listed in the Qatar Exchange for the period between 2006-2011. This study included different dimensions of ownership structure, and those were: board ownership, concentrated ownership, foreign ownership, and institutional ownership. In addition, firm performance is estimated by three measures: Tobin's Q, ROA, and ROE. Results displayed a positive impact on a firm's performance due to concentrated ownership, board ownership, and foreign ownership. In addition, Eulaiwi et al.,(2016) outside board directorship and family ownership concentration was studied in this research. From non-financial publicly listed firms from Gulf Cooperation Countries, a sample of 1091 firm-year observations was collected from 2005 to 2013 and found a positive relationship between family ownership and the number of board members holding directorship from outside. Moreover, (Sulong \& Nor, 2010) studied the outcome of governance mechanisms of dividend, types of ownership structure, and board governance on firm value. This paper 
utilizes a panel data analysis of 403 firms listed on Bursa Malaysia over four years from years 2002 to 2005. Findings highlighted the significance of the moderating role played by board governance variables with the kind of ownership structure to influence the firm's value.

Furthermore,(Briano-Turrent et al., 2016; Brown \& Caylor, 2009) found that the corporate ownership score has a positive and significant impact on financial performance. Similarly, García-Meca \& Sánchez-Ballesta, (2011) examined the effects on Tobin's Q of various dimensions of the Spanish ownership structure likely to represent conflicting interests: ownership concentration, insider ownership, and bank ownership on the Spanish market. The study revealed a significant positive impact of concentrated ownership on the firm's performance up to a certain level. Still, when that was increased beyond that level, the influence becomes negative. However, the relationship between the insider and institutional ownership is insignificant with the performance of the firm. Table 1 shows the most recent empirical results of the relationship between corporate ownership characteristics and firms' performance. Finally, various studies have investigated ownership structure in different context (e.g., Hashed \& Almaqtari, 2020; Al-Ahdal \& Almaqtari, et al., 2020; Almaqtari \& Hashed, et al., 2020; Farhan et al., 2020; Almaqtari \& Shamim et al., 2020; Almaqtari \& Al-Hattami et al., 2020; Al Maqtari \& Farhan et al., 2020) however, these studies have examined ownership structure based on secondary data.

Table 1. Empirical results of the relationship between ownership structure and firm performance.

\begin{tabular}{|c|c|}
\hline Study & Main Results \\
\hline Srivastava \& Bhatia, (2020) & $\begin{array}{l}\text { The findings suggested that family ownership and firm performance have a nonlinear } \\
\text { relationship, and family ownership positively impacts firm performance to a certain } \\
\text { point. After that, it starts affecting firm performance negatively. This study also found } \\
\text { that family involvement in governance positively affects firm performance. }\end{array}$ \\
\hline Wang et al., (2019) & $\begin{array}{l}\text { Findings showed that ownership concentration positively affects firm performance } \\
\text { and corporate ownership leads to higher firm performance than financial ownership. } \\
\text { The study showed that firms in China benefit more from foreign ownership than firms } \\
\text { with only domestic ownership. }\end{array}$ \\
\hline Kao et al.,(2019) & $\begin{array}{l}\text { Findings depict that ownership structure, block-holders' ownership, institutional } \\
\text { ownership, foreign ownership, and family ownership are all positively related to firm } \\
\text { value. }\end{array}$ \\
\hline Altaf \& Shah, (2018) & $\begin{array}{l}\text { The study's results confirm the inverted U-shaped relationship between ownership } \\
\text { concentration and firm performance and a significant positive effect of investor } \\
\text { protection quality on firm performance. }\end{array}$ \\
\hline Al-Bassam et al, (2018) & $\begin{array}{l}\text { The study's results suggest that corporations with higher government ownership and } \\
\text { higher institutional ownership disclose considerably more than those that are not. }\end{array}$ \\
\hline Hanafi et al., (2018) & $\begin{array}{l}\text { They found that ownership concentration improves firm performance. Moreover, the } \\
\text { large firms have a more substantial impact of ownership on firms' value. }\end{array}$ \\
\hline Manna et al, (2017) & $\begin{array}{l}\text { The study results indicated that the performance of the Indian listed companies is } \\
\text { significantly affected by ownership structure and board composition. }\end{array}$ \\
\hline Yasser \& Mamun, (2017) & $\begin{array}{l}\text { Findings show a significant positive association between ownership structure and } \\
\text { both market-based performance measures and economic profit. The ownership } \\
\text { proportion of institutional shareholding and foreign shareholding is also positively } \\
\text { associated with firm performance. }\end{array}$ \\
\hline
\end{tabular}

The research hypotheses concerning the objectives of the study and accordance with the literature review are as follows:

H1: There is a negative relationship between the ownership structure Index and firm performance. 


\section{Research Methodology}

\subsection{Data collection and study period}

This study is mainly conducted to examine the influence of ownership structure on Indian Nifty 100 listed companies' performance. NIFTY 100 represents the top 100 companies based on full market capitalization. The purpose of the index is to compute the performance of large market capitalization companies. This index intends to measure the performance of large market capitalization companies. The NIFTY 100 Index represents about $76.8 \%$ of the free-float market capitalization of the stocks listed on NSE as of March 29, 2019, according to the NSE (https://www.nseindia.com accessed on April 24, 2019) focus of the present study is only on non-financial firms, a sample of 73 firms out of 100 was chosen based on the availability of the data, and they are non-financial listed firms for the time period eight years with 584 observation from 2009 to 2016 . The Prowess, QI database was used for gathering financial data and leverage, whereas ownership structure data was retrieved from the corporate governance reports from the annual reports of the selected sample companies.

\subsection{Concepts and measurements of variables in the study}

\subsubsection{Dependent variables.}

Return of Assets (ROA): ROA is measured as the percentage of a year's net profit to the total assets of the same year. ROA = Net Profit / Total Asset (Haniffa \& Hudaib, 2006; Sami et al., 2011)

Return on equity (ROE): ROE is measured as the percentage of a year's net profit to the total equity of the same year. ROE= Net Profit /Total Equity. (Aggarwal, 2013; Varshney et al., 2013).

\subsubsection{Explanatory variables.}

Table 2.Explanatory variables

\begin{tabular}{|c|c|c|}
\hline Ownership Structure Index & $\begin{array}{l}\text { 1. List of major shareholders and number (percentage) of shares held } \\
\text { by them. } \\
\text { 2. Information about share voting and voting agreements } \\
\text { 3. Availability of Investor Relations contact detail } \\
\text { 4. Disclosure of foreign ownership } \\
\text { 5. No. of shares that directors and officers are holding has not } \\
\text { decreased by } 10 \% \text { or more. } \\
\text { 6. No. of shares that directors and officers are holding has increased } \\
\text { by } 10 \% \text { or more. } \\
\text { 7. Transparency of Capital structure } \\
\text { 8. Government ownership is disclosed } \\
\text { 9. Company has a policy against insider trading } \\
\text { 10. Institution ownership is disclosed }\end{array}$ & $\begin{array}{l}\text { (Abdallah \& } \text { Ismail, 2017; Al- } \\
\text { Malkawi et al., 2014; Srairi, } \\
\text { 2015; } \quad \text { Prusty \& Al-ahdal., } \\
2018 \text { ) }\end{array}$ \\
\hline
\end{tabular}

\subsubsection{Control variable.}

i. Firm size: Studies conducted in the past used total assets as a proxy for measuring the firm's size. More specifically, they are commonly used in the natural logarithm of total assets to measure the firm's size. (Arora \& Sharma, 2016; Al-ahdal et al., 2020)

ii. Leverage (LEV): Total debt percentage is divided by total assets. LEV= total debt / total assets(Abdallah \& Ismail, 2017; Al-ahdal et al., 2020). 


\subsection{Model Specification}

Consistent with previous literature ( Al-ahdal \& Prusty,2020; Dabor et al., 2015; Fauzi \& Musallam, 2015; Hussein, 2013), we developed the following model to inquire into the impact of ownership structure on company performance.

$$
\begin{aligned}
& \mathrm{ROA}_{i \mathrm{t}}=\alpha+\beta_{1} \mathrm{OSI}_{\mathrm{it}}+\beta_{2} \mathrm{LEV}_{\mathrm{it}}+\beta_{4} \mathrm{FSIZE}_{\mathrm{it}}+\varepsilon_{\mathrm{it}} \\
& \mathrm{ROE}_{\mathrm{it}}=\alpha+\beta_{1} \mathrm{OSI}_{\mathrm{it}}+\beta_{2} \mathrm{LEV}_{\mathrm{it}}+\beta_{4} \mathrm{FSIZE}_{\mathrm{it}}+\varepsilon_{\mathrm{it}}
\end{aligned}
$$

Where:

$$
\begin{aligned}
& \alpha=\text { intercept } \\
& \varepsilon_{\text {it }}=\text { error term } \\
& \beta=\text { beta } \\
& \mathrm{ROA}_{\mathrm{it}}=\text { Return on asset } \\
& \mathrm{ROE}_{\mathrm{it}}=\text { Return on equity }
\end{aligned}
$$

OSI is the ownership structure index of the companies

LEV is the corporate leverage; measured by total debt to total assets

FSIZE is the firm size

\section{Results and Discussion}

\subsection{Descriptive Statistics}

Descriptive statistics of the variables that are used in the study is shown in the descriptive analysis table 3. The mean values for ROA and ROE from 2009 to 2016 are 11.51 and 21.45, respectively. However, the ranges of ROA and ROE are from the lowest value of -8.78 and -18.3 to the highest value of 38.71 and 86.91 , respectively. The table also shows that the independent variable ownership structure index mean value is a higher percentage among all variables of listed companies with a mean of 79.87 for the period between 2019 and 2016. It is also obvious from the table that the mean of firm size for the sample as a whole during 2019-2016 was 5.25, ranging from 2 to 10. Similarly, the mean value of leverage was 13.33 , ranging from 0.01 to 91 .

Table 3. Descriptive Statistics

\begin{tabular}{lllllll}
\hline Particulars & $\mathrm{N}$ & ROA & ROE & OS & FSIZE & LEV \\
\hline Mean & 584 & 11.51 & 21.45 & 79.87 & 5.25 & 13.33 \\
Median & 584 & 10.59 & 19.33 & 78.6 & 5.119 & 0.69 \\
Maximum & 584 & 38.71 & 86.91 & 92.9 & 10.13 & 91.20 \\
Minimum & 584 & -8.78 & -18.3 & 57.1 & 2.17 & 0.01 \\
Std. Dev. & 584 & 8.10 & 16.28 & 13.51 & 0.94 & 24.27
\end{tabular}




\subsection{Correlation analysis}

- Pearson's correlation was used in this study to measure the degree of association between the independent variables. Results of the correlation were shown in table 4. On the basis of the products, there was no correlation coefficient, which showed no value higher than 5 , there was no problem with multicollinearity (Judge et al., 1988).

Table 4. Correlation matrix between variables

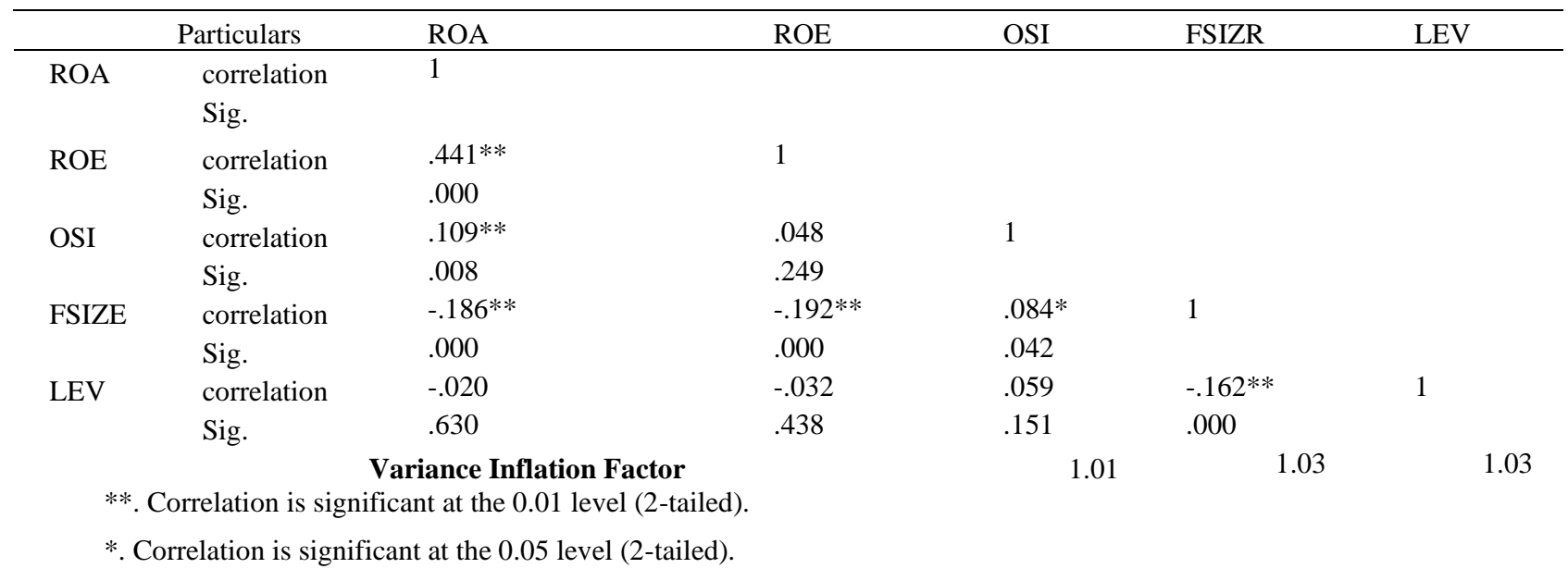

In measuring the association between all the variables and the ROA and ROE as a measurement of firm performance, it was found that the ownership structure index has a significant positive relation with ROA and positive but insignificant with ROE. On the other hand, firm size and leverage have a positive relationship with ROA and ROE, but it is not significant in the case of leverage, while it is significant in the case of firm size.

\subsection{The unit root test}

The stationary of the study variables was tested using the Augmented Dickey-Fuller (ADF) test and Phillip-Person Test. The results of table 5 indicate that the data at the first difference is stationary at $\alpha 1 \%, 5 \%$, and $10 \%$ level of significance, respectively. Results of the ADF test and Phillip-Person Test, at the level, indicate that all variables are stationary, which leads to the fact that the unit root null hypothesis can be rejected. Table 5 shows the results of P-Values of ADF and Phillip-Person Test for all variables at the level and first difference.

Table 5.Unit root test

\begin{tabular}{lllll}
\hline Particulars & \multicolumn{3}{c}{ ADF Test } & Phillip-Person Test \\
\cline { 2 - 5 } & Level & Frist deference & Level & Frist deference \\
\hline Variable & t- statistic & t- statistic & t- statistic & P value \\
& P value & P value & P value & 192.111 \\
\hline ROA & 227.57 & & 0.0063 & \\
ROE & 0.0000 & & 183.641 & \\
& 242.93 & & 0.0019 & \\
OSI & 0.0000 & & 97.5494 & 0.0109 \\
& 98.0131 & & 309.971 & \\
FSIZE & 0.0001 & & 0.000 & 190.731 \\
LEV & 212.805 & & 0.0076 &
\end{tabular}




\subsection{Regression analysis}

The results of the impact of ownership structure on companies' performance of Indian Nifty 100 listed companies are presented in table 6. Hence, the Hausman test was conducted to decide between the fixed effect model and the random effect model, as shown in table 6 . The results indicated that the fixed effect model is preferred to the Random effect model in both model ROA and ROE. The selected regressions models were performed, and the findings are presented in table 6. The two regression models have significant explanatory power with R-squares ranging from 0.78 to 0.89 .

Table 6. Regression Result

\begin{tabular}{|c|c|c|c|c|c|c|c|c|c|}
\hline \multicolumn{5}{|c|}{ Model(1) ROA } & \multicolumn{5}{|c|}{ Model(2) ROE } \\
\hline Variables & Coefficient & $\begin{array}{c}\text { Std. } \\
\text { Error }\end{array}$ & $\mathrm{t}$-Statistic & Prob. & Variables & Coefficient & Std. Error & t-Statistic & Prob. \\
\hline $\mathrm{C}$ & 20.85 & 4.34 & 4.80 & 0.00 & $\mathrm{C}$ & 48.37 & 8.51 & 5.67 & 0.00 \\
\hline OS & -0.083 & 0.05 & -1.65 & 0.047 & OS & -0.26 & 0.099 & -2.67 & 0.007 \\
\hline FSIZE & -0.596 & 0.49 & -1.21 & 0.224 & FSIZE & -1.21 & 0.96 & -1.26 & 0.207 \\
\hline LEV & 0.037 & 0.035 & 1.05 & 0.291 & LEV & 0.052 & 0.06 & 0.75 & 0.452 \\
\hline $\begin{array}{l}\text { Prob(F- } \\
\text { statistic) }\end{array}$ & \multicolumn{4}{|c|}{0.0000} & $\begin{array}{l}\text { Prob(F- } \\
\text { statistic) }\end{array}$ & \multicolumn{4}{|c|}{0.0000} \\
\hline $\begin{array}{c}\mathrm{R}^{2} \\
\text { Durbin- }\end{array}$ & \multicolumn{4}{|c|}{0.79} & $\begin{array}{c}\mathrm{R}^{2} \\
\text { Durbin- }\end{array}$ & \multicolumn{4}{|c|}{0.78} \\
\hline Watson & \multicolumn{4}{|c|}{1.25} & Watson & \multicolumn{4}{|c|}{1.39} \\
\hline
\end{tabular}

Models (1) and (2) in Table (6) investigated the effect of ownership structure on the performance of the company of Indian Nifty 100 listed companies. Findings in Table (6) illustrate that OSI has an significant impact on a firm's performance measured by ROA and ROE; this result is supported by (Fauzi \& Musallam, 2015; Ozili \& Uadiale, 2017). The findings of this study also disagree with (AlMatari et al., 2014). Regarding FSIZE, model (1) and (2) demonstrate that FSIZE has insignificant impact on ROA and ROE ; this result is associated with (Aggarwal, 2013; Almudehki \& Zeitun, 2011; Eulaiwi et al.,2016). Moreover, there is a positive and statistically insignificant association between LEV and ROA and ROE. This result contradicts (Ehikioya, 2016).

\section{Conclusion}

This paper examines the relationship between ownership structure indexes on financial performance using panel data of 73 companies that are listed on the Indian national stock exchange during a period of 2009 to 2016. Hence, there is little guidance from academic research on how considerable the potential valuation benefits associated with good corporate governance, in fact, are upon the financial performance in the method of fixed effect model to estimate the panel data regression. The results of the study show that the effect of ownership structure has significant impact on company performance of Indian Nifty 100 listed companies measured by ROA and ROE. Therefore, this study supports the previous empirical results and adds value to financing research that explores the different aspects of the board of director's index and ownership structure index in the Indian market by using Nifty 100 as an example. Furthermore, this study will be more interested if all listed firms in the national stock exchange market are included in the analysis. 


\section{References}

[1] Abdallah, A. A., \& Ismail, A. K. (2017). Corporate governance practices, ownership structure, and corporate performance in the GCC countries. Journal of International Financial Markets, Institutions \& Money, 46, 98-115. https://doi.org/10.1016/j.intfin.2016.08.004

[2] Aggarwal, P. (2013). Impact of Corporate Governance on Corporate Financial Performance. IOSR Journal of Business and Management, 13(3), 01-05. https://doi.org/10.9790/487X-1330105

[3] Al-ahdal, W. M., Alsamhi, M. H., Tabash, M. I., \& Farhan, N. H. (2020). The impact of corporate governance on financial performance of Indian and GCC listed firms: An empirical investigation. Research in International Business and Finance, 51, 101083.

[4] Al-ahdal, W. M., \& Prusty, T. (2020). Does board structure index and ownership structure index impact on top listed Indian company's performance?. International Journal of Business Governance and Ethics, 14(4), 436-450.

[5] Al-Ahdal, W.M., Almaqtari, F.A., Zaid, D.A., Al-Homaidi, E.A. and Farhan, N.H. (2020), "Corporate characteristics and leverage: evidence from Gulf countries", PSU Research Review, Vol. ahead-of-print No. ahead-of-print. https://doi.org/10.1108/PRR-01-2020-0001

[6] Al-Bassam, W. M., Ntim, C. G., Opong, K. K., \& Downs, Y. (2018). Corporate Boards and Ownership Structure as Antecedents of Corporate Governance Disclosure in Saudi Arabian Publicly Listed Corporations. Business and Society, 57(2), 335-377. https://doi.org/10.1177/0007650315610611

[7] Al-Malkawi, H. A. N., Pillai, R., \& Bhatti, M. I. (2014). Corporate governance practices in emerging markets: The case of GCC countries. Economic Modelling, 38, 133-141. https://doi.org/10.1016/j.econmod.2013.12.019

[8] Al-Matari, E. M., Al-Matari, Y. A., \& Saif, S. A. (2017). Ownership Structure, Audit Quality and Firm Performance Moderating and Direct-Effect Models: an Empirical Study. Corporate Board: Role, Duties and Composition, 13(1). https://doi.org/10.22495/cbv13i1p3

[9] Al-Matari, E. M., Al-Swidi, A. K., \& Fadzil, F. H. B. (2014). Audit committee characteristics and executive committee characteristics and firm performance in Oman: Empirical study. Asian Social Science, 10(12), 98-113. https://doi.org/10.5539/ass.v10n12p98

[10] Almaqtari, F. A., Hashed, A. A., Shamim, M., \& Al-ahdal, W. M. (2020). Impact of corporate governance mechanisms on financial reporting quality: a study of Indian GAAP and Indian Accounting Standards. Problems and Perspectives in Management, 18(4), 1.-13. https://doi.org/10.21511/ppm.18(4).2020.01

[11] Almaqtari, F. A., Shamim, M., Al-Hattami, H. M., \& Aqlan, S. A. (2020). Corporate governance in India and some selected Gulf countries. International Journal of Managerial and Financial Accounting, 12(2), 165-185. https://doi.org/10.1504/IJMFA.2020.109135

[12] Almaqtari, F. A., Al-Hattami, H. M., Al-Nuzaili, K. M., \& Al-Bukhrani, M. A. (2020). Corporate governance in India: A systematic review and synthesis for future research. Cogent Business \& Management, 7(1), 1803579. https://doi.org/10.1080/23311975.2020.1803579

[13] Al Maqtari, F. A., Farhan, N. H., Al-Hattami, H. M., \& Khalid, A. S. (2020). Impact of country-level corporate governance on entrepreneurial conditions. Cogent Business \& Management, 7(1), 1797261. https://doi.org/10.1080/23311975.2020.1797261

[14] Almudehki, N., \& Zeitun, R. (2011). Ownership structure and corporate performance: evidence from Qatar. Available at SSRN 2154289.

[15] Arora, A., \& Sharma, C. (2016). Corporate Governance and Firm Performance in Developing Countries: Evidence from India. Corporate Governance: The International Journal of Business in Society, 16(2). https://doi.org/doi.org/10.1108/CG-01-2016-0018

[16] Briano-Turrent, G. del C., \& Rodríguez-Ariza, L. (2016). Corporate governance ratings on listed companies: An institutional perspective in Latin America. European Journal of Management and Business Economics, 25(2), 63-75. https://doi.org/10.1016/j.redeen.2016.01.001

[17] Brown, L. D., \& Caylor, M. L. (2009). Corporate governance and firm operating performance. Review of Quantitative Finance and Accounting, 32(2), 129-144. https://doi.org/10.1007/s11156-007-0082-3

[18] Dabor, A. O., Isiavwe, D. T., Ajagbe, M. A., \& Oke, A. O. (2015). Impact of Corporate Governance on Firm Performance. International Journal of Economics, Commerce and Management, 3(6), 634-653. https://doi.org/10.5539/ijef.v6n6p1 
[19] Ehikioya, B. (2016). Corporate governance structure and firm performance in developing economies: evidence from Nigeria. Corporate Governance: The International Journal of Business in Society, 9(3), 231-243. https://doi.org/10.1108/14720700910964307

[20] Eulaiwi, B., Al-hadi, A., Taylor, G., Al-yahyaee, K. H., \& Evans, J. (2016). Multiple directorships , family ownership and the board nomination committee : International evidence from the GCC. Emerging Markets Review, 28, 61-88. https://doi.org/10.1016/j.ememar.2016.06.004

[21] Farhan, N., Tabash, M., Almaqtari, F., \& Yahya, A. (2020). Board composition and firms' profitability: Empirical evidence from pharmaceutical industry in India. Journal of International Studies, 13(3), 180194. https://doi.org/10.14254/2071- 8330.2020/13-3/12

[22] Fauzi, H., \& Musallam, S. R. M. (2015). Corporate ownership and company performance : a study of Malaysian listed companies. Social Responsibility Journal, 11(3), 439-448. https://doi.org/10.1108/SRJ05-2014-0064

[23] García-Meca, E., \& Sánchez-Ballesta, J. P. (2011). Firm value and ownership structure in the Spanish capital market. Corporate Governance, 11(1), 41-53. https://doi.org/10.1108/14720701111108835

[24] Hanafi, M. M., Setiyono, B., \& Sanjaya, I. P. S. (2018). Ownership structure and firm performance: evidence from the subprime crisis period. Corporate Governance (Bingley), 18(2), 206-219. https://doi.org/10.1108/CG-10-2016-0203

[25] Haniffa, R., \& Hudaib, M. (2006). Corporate Governance Structure and Performance of Malaysian Listed Companies. Journal of Business Finance and Accounting, 33(7-8), 1034-1062. https://doi.org/10.1111/j.1468-5957.2006.00594.x

[26] Hashed, A., \& Almaqtari, F. (2020). The impact of corporate governance mechanisms and IFRS on earning management in Saudi Arabia. Accounting, 7(1), 207-224. https://doi.org/10.5267/j.ac.2020.9.015

[27] Himmelberg, C. P., Hubbard, R. G., \& Palia, D. (1999). Understanding the Determinants of Managerial Ownership and the Link between Ownership and Performance. Journal of Financial Economics, 53, 353384.

[28] Hussein, S. K. (2013). Corporate Governance and Firm' s Value: An Empirical Analysis of Agri -input firms in India. International Journal of Commerce, Business and Management, 2(6), 353-362.

[29] Judge, G., Hill, C., Griffiths, E., Lutkepohl, H. and Lee, T.C. (1988), Introduction to the Theory and Practice of Econometrics, 2nd ed., John Wiley and Sons, New York, NY.

[30] Kao, M. F., Hodgkinson, L., \& Jaafar, A. (2019). Ownership structure, board of directors and firm performance: evidence from Taiwan. Corporate Governance (Bingley), 19(1), 189-216. https://doi.org/10.1108/CG-04-2018-0144

[31] La Porta, R., Lopez-de-Silanes, F., Shleifer, A., \& Vishny, R. (1998). Law and Finance. Journal of Political Economy, 106, 1113-1155.

[32] Manna, A., Sahu, T. N., \& Gupta, A. (2017). Impact of ownership structure, board composition and CEO characteristics on corporate performance: An indian study. Asian Journal of Research in Business Economics and Management, 7(7), 100. https://doi.org/10.5958/2249-7307.2017.00101.3

[33] OECD. (1999). OECD principles of corporate governance, OECD Publishing, Paris. Available at: http://www.oecd.org/officialdocuments/publicdisplaydocumentpdf/

[34] Ozili, P. K., \& Uadiale, O. (2017). Ownership concentration and bank profitability, 3, $159-171$. https://doi.org/10.1016/j.fbj.2017.07.001

[35] Prusty, T., \& Waleed, M. Al-ahdal., 2018. Corporate Governance and profitability: Evidence from Indian IT companies, Financial Markets, Institutions and Risks, 2(3).

[36] Rusyda, Z. T. (2018). The Effect of Ownership Structure on Firm Performance.pdf. Yogyakarta State University Approved.

[37] Sami, H., Wang, J., \& Zhou, H. (2011). Corporate governance and operating performance of Chinese listed firms. Journal of International Accounting, Auditing and Taxation, 20(2), 106-114. https://doi.org/10.1016/j.intaccaudtax.2011.06.005

[38] Srairi, S. (2015). Corporate governance disclosure practices and performance of Islamic banks in GCC countries. Journal of Islamic Finance, 4(2), 1-17.

[39] Srivastava, A., \& Bhatia, S. (2020). Influence of Family Ownership and Governance on Performance: Evidence from India. Global Business Review. https://doi.org/10.1177/0972150919880711

[40] Sulong, Z., \& Nor, F. (2010). Corporate governance mechanisms and firm valuation in Malaysian listed firms : A panel data analysis. Journal of Modern Accounting and Auditing, 6(1), 1-18. 
[41] Varshney, P., Kaul, V. K., \& Vasa, V. K. (2013). Corporate governance mechanisms and firm performance : a study of select Indian firms. Afro-Asian Journal. Finance and Accounting, 3(4).

[42] Wang, H., Wu, J., Yang, Y., Li, R., \& Liu, Y. (2019). Ownership Concentration, Identity and Firm Performance: Evidence from China's Listed Firms. Emerging Markets Finance and Trade, 55(15), 36533666. https://doi.org/10.1080/1540496X.2019.1672042

[43] Yasser, Q. R., \& Mamun, A. Al. (2017). The Impact of Ownership Concentration on Firm Performance: Evidence from an Emerging Market. Emerging Economy Studies, 3(1), $34-53$. https://doi.org/10.1177/2394901517696647 